\section{Grasping nettles}

\author{
Jeremy Purseglove
}

Wetlands: A Threatened Landscape. Edited by Michael Williams. Blackwell: 1991. Pp.419. £70, \$79.95.

THIS is a very dry book on wetlands. It is, nonetheless, a great mine of information, assembled by a distinguished group of authors, and provides a solid background to the wetland debate. Wetlands are guaranteed to fuel controversy if, as recognized in the last chapter, their conservation involves "redistributing of rights to use the environment and by implication an allocation of wealth". Legislating to resolve these debates is, as the authors frequently suggest, fraught with the difficulty of conflicting subjective values. Still, if their creed that wetland destruction "should not be undertaken without much thought and good cause" is not to be totally flouted, some nettles will need to be grasped. In the developed world an over-powerful and greedy agricultural lobby should not be able to lay its hands on inappropriate subsidies for wetland drainage. And those who grant foreign aid to developing countries need to understand that local people are often best served economically by harvesting indigenous wetlands, or at least by partial reclamation and mixed cropping, rather than

Swamped by possibilities - land ripe for conservation, preservation, commercialization and deforestation.

by grandiose imported drainage schemes.

"The most comprehensive appraisal of the world's wetlands ever published", is the claim on the dust jacket. The main strength of the book certainly is its breadth. Eutrophication and tourism are described on Lake Dal and on the Norfolk Broads. The port expansion at Singapore can be compared here with that at Rotterdam. There are accounts of mediaeval drainage in the Netherlands, reclamation of the Sundarbans by the British Raj and the impact of the great Gold Rush on the wetlands of San Francisco Bay. There are especially good sections on tropical wetlands.

In spite of its wealth of sources, I was always hungry for yet more examples rather than generalizations. The difficulties of conserving the potholes of North Dakota, the plight of the Florida panther and the spectacular wetland creation schemes of the US shooting organization Ducks Unlimited were typical details constantly needed to bring the issues to

life. The archaeological chapter is an exception to the rest in being vivid with detail. Wetlands near Trento have preserved a cloche hat of woven reed and guelder rose worn by some chic prehistoric Italian. In South Australia, 10,000-

\section{IMAGE UNAVAILABLE FOR COPYRIGHT REASONS}

year-old boomerangs were found in a tree from which the boomerangs were made. Such images really bring home the value of an ancient wetland and are worth pages of academic jargon, here epitomized by a fatuous three-page table describing different recreational attitudes to wetlands ranging from the "negativistic" (killing and draining) to the "moralistic" (animal rights).

A more understandable problem, presumably because of the ambitious breadth of the book, is the lack of space for deep exploration of specific issues. Thus peatlands are touched on, but there is no real discussion of the dilemmas and arguments surrounding afforestation of the Flow Country in Scotland, or the excavation of lowland raised mires in the United Kingdom and the Soviet Union for horticultural peat. Similarly, the increasingly urgent issue of water abstraction receives little coverage. wetland that still supports the species of
Where specific issues are addressed, some conclusions do emerge. As a destroyer of wetlands, recreation is not in the same league as urban development or intensive agriculture. Although tourists at Kakudu National Park in Northern Australia "couldn't be trusted with rifles" and even "got themselves into trouble by tempting the crocodiles" (one solution to the problem?), careful design of campsites and access roads minimized the tourists' impact on the reserve. For similar reasons, the effect of 400,000 annual visitors to the Everglades is reported as "slight". The big business in tourism, such as that on the s. shores of Lake Erie, may even prove to be the salvation of wetlands by warding off other threats.

The case is well made that, for the wetlands of developing countries, both human inhabitants and wildlife are worse off after major drainage schemes. Thus drainage of the Sudd could leave most of those without access to land even having to import their own food. But the authors are also honest enough to accept that swamps and forests converted to rice paddy-fields in South-East Asia are now "immensely productive wetlands which feed great numbers of human beings every year". Wholesale generalizations can no more be applied to the wetland debate any more than to any other issue.

Maps are generally excellent. Photographs vary from a splendid shot of buses marooned in a Somerset flood to what appears to be the professor's holiday snaps taken with his brownie box. Blobs in the distance may be hippos, storks or mud skippers, but you will need to check the caption to be sure. Publishers have no excuse for wasting space in a $£ 70$ book on such pictures, as if a work of scholarship is somehow demeaned by attractive presentation. Nevertheless, for those who can afford it, this is a remarkably wide-ranging compendium of knowledge about wetlands.

Jeremy Purseglove is a landscape architect at the civil engineering firm Mott MacDonald, Cambridge, UK, and author of Taming the Flood, which describes the history and current status of the rivers and wetlands of Europe (Oxford University Press, 1989).

Wetlands has just been published by Facts on File, in association with The International Waterfowl and Wetlands Research Bureau (general editors, Max Finlayson and Michael Moser). Price is $£ 19.95$. 